\title{
Penerapan Model Cooperative Script dalam Peningkatan Kerjasama dan Komunikasi pada Tema Panas dan Perpindahannya Siswa Kelas V SD N 1 Bumirejo Tahun Ajaran 2018/2019
}

\author{
1,2,3Universitas Sebelas Maret \\ Ingtiarti00@gmail.com
}

Ingtiarti ${ }^{1}$, Kartika Chrysti Suryandari ${ }^{2}$, Tri Saptuti Susiani ${ }^{3}$

Article History
accepted 01/10/2019

approved 01/11/2019

\begin{abstract}
The Application of Cooperative Script Model in Increasing Cooperation and Communication in the Theme of Heat and Its Transfer of Grade V Students of SD N 1 Bumirejo in Academic Year 2018/2019. This study aimed to analyze the steps of applying cooperative script models to improve collaboration and communication on the theme of heat and its transfer of Grade V students of SD N 1 Bumirejo in Academic Year 2018/2019. This study used Class Action Research (CAR). This research was conducted in fifth grade students of SD N 1 Bumirejo with the teacher as the executor of the action. The types of data used were quantitative and qualitative data. The instruments of data collection were in the form of observation sheets, interviews, questionnaires, and the results of the pretest and posttest. The data collection technique used was triangulation technique. The results of this study indicated that students' cooperation and communication increased through the implementation of cooperative script models on the theme of heat and its transfer in fifth grade students of elementary school.
\end{abstract}

Keywords: cooperative script model, cooperation, communication

\section{Abstrak}

Penerapan Model Cooperative Script dalam Peningkatan Kerja Sama dan Komunikasi Pada Tema Panas dan Perpindahannya Siswa Kelas V SD N 1 Bumirejo Tahun Ajaran 2018/2019. Penelitian ini bertujuan untuk menganalisis langkah-langkah penerapan model cooperative script untuk meningkatkan kerja sama dan komunikasi pada tema Panas dan Perpindahannya siswa kelas V SD N 1 Bumirejo tahun ajaran 2018/2019. Jenis penelitian yang digunakan yaitu penelitian tindakan kelas (PTK). Penelitian ini dilaksanakan di kelas V SD N 1 Bumirejo dengan guru sebagai pelaksana tindakan. Jenis data yang digunakan adalah data kuantitatif dan kualitatif. Instrumen pengumpulan data berupa lembar observasi, wawancara, angket serta hasil pretest dan posttest. Teknik pengumpulan data yang digunakan adalah teknik triangulasi. Hasil penelitian ini menunjukkan bahwa kerja sama dan komunikasi siswa meningkat melalui penerapan model cooperative script pada tema Panas dan Perpindahannya di kelas V SD.

Kata kunci: model cooperative script, kerja sama, komunikasi 


\section{PENDAHULUAN}

Pendidikan menjadi hal yang penting dalam membentuk siswa yang berkualitas dan memiliki keca-kapan serta keterampilan pada abad 21. Membentuk generasi yang ber-kualitas dalam bidang pendidikan dapat dilakukan pada pembelajaran di sekolah dengan menerapkan kom-petensi-kompetensi abad 21. Kompe-tensi abad 21 adalah kompetensi atau kecakapan yang harus dimiliki oleh siswa dalam mengha-dapi kehidupan dan dunia kerja. Menurut Hosnan, M (2014: 87) kecakapan yang dibutuhkan pada abad ini disebut 4C yaitu, communi-cation skill (kecakapan ko-munikasi), collaboration skill (kola-borasi atau kerjasama), critical thin-king and problem solving skill (keca-kapan berpikir kritis dan pemecahan masalah), creativity and innovation skill (kecakapan kreativitas dan inovasi).

Berkaitan dengan kompetensi abad 21, pembelajaran tematik pada kurikulum 2013 mendukung pembe- lajaran yang menerapkan keteram-pilan atau kompetensi pada abad ter-sebut. Pembelajaran tematik yang dilaksanakan pada kurikulum 2013 ini lebih berpusat pada siswa (student centered learning). Menurut Permen-dikbud Nomor 22 Tahun 2016 tentang Standar Proses pada kuriku-lum 2013 menggunakan tiga model pembelajaran yaitu, (1) model pem-belajaran melalui penyingkapan/ penemuan (discovery/inquiry lear-ning), (2) model pembelajaran berba-sis masalah (Problembased Lear-ning/PBL), (3) model pembelajaran berbasis projek (Project based Learning/PJBL) (Kemendikbud, 2018 : 29). Selain tiga model tersebut, pem-belajaran dapat pula dikembangkan melalui model cooperative learning atau pembelajaran kelompok (Ke-mendikbud, 2018 : 29). Dari bebe-rapa keterampilan dan sikap diatas menjelaskan bahwa keterampilan be-kerjasama dan berkomunikasi meru-pakan keterampilan yang ditum-buhkan pada pembelajaran tematik kurikulum 2013.

Berdasarkan observasi dan wawancara yang telah dilakukan pada tanggal 19 Oktober 2018 di SDN 1 Bumirejo menunjukkan bah-wa kerjasama siswa rendah yang dilihat saat kegiatan pembelajaran berlangsung yaitu, (1) tugas tidak dibagi secara merata, ketika belajar kelompok sedang berlangsung tidak semua siswa berdiskusi dan me-ngerjakan tugas; (2) siswa kurang menghargai pendapat teman, ada beberapa siswa yang memotong pembicaraan dan langsung menga-takan tidak setuju ketika temannya sedang berpendapat pada saat dis-kusi; (3) kurangnya partisipasi siswa, ketika berdiskusi beberapa siswa tidak ikut mengerjakan tugas kelom-pok, tidak mengajukan pendapat dan tidak menanggapi pendapat teman sehingga kurang adanya interaksi antar siswa dalam kelompok. Dilihat dari nilai hasil Penilaian Tengah Semester (PTS) di kelas V pada mata pelajaran IPS dengan KKM 65 me-nunjukkan siswa tuntas sebanyak 13 (48\%) dan siswa tidak tuntas seba-nyak 14 (52\%). Adapun untuk hasil PTS mata pelajaran PPKn dengan KKM 70 menunjukkan siswa tuntas sebanyak 11 (40\%) dan siswa tidak tuntas sebanyak 16 (60\%).

Berdasarkan permasalahan di-atas, peneliti memiliki alternatif untuk memecahkan permasalahannya yaitu dengan menggunakan model pembelajaran kooperatif yang dapat meningkatkan kerjasama dan komu-nikasi tulisan siswa. Model pembe-lajaran tersebut yaitu model pembe-lajaran cooperative script. Rumusan masalah dari penelitian ini yaitu: (1) bagaimanakah langkah-langkah pe-nerapan model cooperative script, (2) apakah penerapan model coope-rative script dapat meningkatkan kerja sama, (3) apakah penerapan model cooperative script dapat me-ningkatkan komunikasi siswa. Adapun tujuan dari penelitian ini yaitu: (1) menganalisis langkahlangkah pene-rapan model cooperative script, (2) meningkatkan kerjasama siswa mela-lui penerapan model cooperative script, dan (3) meningkatkan komunikasi siswa melalui penerapan model coo-perative script.

\section{METODE}

Jenis penelitian yang digunakan adalah penelitian tindakan kelas (PTK). Penelitian ini dilaksanakan di SD Negeri 1 Bumirejo kecamatan Kebumen kabupaten Kebumen. 
Sub-jek penelitian pada penelitian ini adalah seluruh siswa kelas V SD Negeri 1 Bumirejo tahun ajaran 2018/2019 yang berjumlah 26 siswa.

Data yang digunakan dalam penelitian ini yaitu data kuantitatif dan data kualitatif. Sumber data dari penelitian ini yaitu guru dan siswa. Teknik pengumpulan data yang digunakan yaitu observasi, wawan-cara, angket, dan tes. Dalam pene-litian ini menggunakan teknik pe-ngumpulan data triangulasi, yaitu triangulasi teknik dan triangulasi sumber. Analisis data meliputi re-duksi data, penyajian data, dan kesimpulan sesusi model analisis data menurut Miles dan Huberman (Sugiono, 2012: 246-253). Prosedur penelitian meliputi tahap peren-canaan (planning), tahap pelaksanaan (acting), tahap pengamatan (observing), dan tahap refleksi (reflecting) (Arikunto, 2013: 137).

\section{HASIL DAN PEMBAHASAN}

Penelitian ini dilaksanakan sela-ma tiga siklus dengan menerapkan langkah model pembelajaran coo-perative scrip yaitu: (1) menyam-paikan materi pembelajaran, (2) membagi kelompok berpasangan, (3) membagikan bahan bacaan, (4) me-ringkas bahan bacaan, (5) mene-tapkan peran, (6) menyampaikan ha-sil diskusi, (7) bertukar peran, (8) menyimpulkan.

Hasil pengamatan penerapan model pembelajaran cooperative script terhadap guru dan siswa mengalami peningkatan pada setiap siklus hingga mencapai indikator kinerja yang ditargetkan yaitu $85 \%$.

Tabel 1. Persentase Rata-rata Hasil Pengamatan Penerapan Mo-del Cooperative Script pada Siklus I, II, dan III

\begin{tabular}{lll}
\hline Langkah & Guru (\%) & Siswa (\%) \\
\hline 1 & 88,9 & 91,7 \\
2 & 83,4 & 84,7 \\
3 & 83,3 & 83,4 \\
4 & 87,5 & 88,9 \\
5 & 82,5 & 81,5 \\
6 & 83,3 & 83,6 \\
7 & 85,2 & 83,3 \\
8 & 86,1 & 87,5 \\
\hline
\end{tabular}

Tabel 2. Persentase Hasil Penga-matan Guru dan Siswa

\begin{tabular}{lllll}
\hline \multirow{2}{*}{ Sumber Data } & \multicolumn{3}{l}{ Siklus } \\
\cline { 3 - 5 } & & & & \\
& & & \\
& & & \\
\hline Guru & $(\%)$ & 73,8 & 87,0 & 92,4 \\
Siswa & $(\%)$ & 77,9 & 87,2 & 91,9
\end{tabular}


Berdasarkan tabel 2, hasil pe-ngamatan terhadap guru pada siklus I sebesar $73,8 \%$, siklus II $87,0 \%$, dan siklus III 92,4\%. Hasil pengamatan terhadap siswa pada siklus I sebesar 77,9\%, siklus II, 87,2\%, dan siklus III 91,9\%. Berdasarkan hasil dari siklus I-III menunjukkan bahwa rata-rata langkah penerapan model cooperative script sudah mencapai indikator kinerja yang diharapkan, yaitu $85 \%$.

\begin{tabular}{cclll} 
Tabel 3. Persentase Hasil Kerja Sama Siswa \\
\begin{tabular}{c} 
Sumber Data \\
\cline { 2 - 4 }
\end{tabular} & \multicolumn{3}{l}{ Siklus } \\
\cline { 2 - 5 } & I & \multicolumn{1}{l}{} & III \\
\hline Siswa & (\%) & 70,0 & 83,3 & 90,8
\end{tabular}

Berdasarkan tabel 3, hasil pe-ngamatan kerja sama terhadap siswa pada siklus I yaitu $70,0 \%$, siklus II $83,3 \%$ dan siklus III sebesar 90,8\%. Berdasarkan hasil tersebut menun-jukkan bahwa siswa melaksanakan kerja sama dengan baik. Hal ini sejalan dengan penelitian Wati, I (2016: 23) bahwa pembelajaran dengan model pembelajaran coo-perative dapat meningkatkan kerja sama siswa.

Tabel 4. Persentase Hasil Komu-nikasi Siswa

\begin{tabular}{lllllll}
\hline Sumber & \multicolumn{2}{l}{ Siklus (\%) } & & & & \\
\cline { 2 - 7 } Data & I & \multicolumn{3}{c}{ II } & \multicolumn{3}{c}{ III } & \\
\hline Pretest & 45 & $\begin{array}{l}\text { Sangat } \\
\text { Rendah }\end{array}$ & 57 & $\begin{array}{l}\text { Sangat } \\
\text { Rendah }\end{array}$ & 68 & Rendah \\
Postest & 71 & Cukup & 73 & Cukup & 86 & Baik \\
\hline
\end{tabular}

Berdasarkan tabel 4, hasil pretest komunikasi tulisan siswa pada siklus I yaitu $45 \%$, siklus II 57\%, dan siklus III 68\%. Hasil posttest komunikasi tulisan siswa pada siklus I yaitu $71 \%$, siklus II $73 \%$, dan siklus III $86 \%$. Dari hasil tersebut menunjukkan bahwa komunikasi tulisan siswa baik dengan indikator komunikasi tulisan (1) mengubah gambar ke kalimat, (2) mengubah kalimat ke gambar dan (3) mengubah skema ke kalimat. Hal ini sejalan dengan penelitian Nur-hikmah, Sudarman Bennu dan Sutji Rochaminah (2016: 99) bahwa pene-rapan model kooperatif tipe TPS dapat meningkatkan komunikasi ma-tematis siswa pada materi Aritmatika Sosial di kelas VIIF SMP Negeri 9 Palu.

\section{SIMPULAN}

Penerapan model pembelajaran cooperative script dapat mening-katkan kerja sama, komunikasi, dan respon siswa pada tema Panas dan Perpindahannya di kelas $\mathrm{V}$ SD N 1 Bumirejo tahun ajaran 2018/2019 dibuktikan dengan peningkatan per-sentase yang memenuhi ketercapaian target sebesar $85 \%$.

\section{DAFTAR PUSTAKA}

Arikunto, Suhardjono, \& Supardi. (2010). Penelitian Tindakan Kelas. Jakarta: Bumi Aksara.

Arikunto, S. (2013). Prosedur Penelitian: Suatu Pendekatan Praktik. Jakarta: Rineka Cipta. 
Hosnan, M. (2014). Pendektan Sain-tifik dan Kontekstual dalam Pembelajaran Abad 21. Bogor: Ghalia Indonesia.

Kemendikbud. (2017). Buku Guru Tema 6 Panas dan Perpin-dahannya. Jakarta: Kementerian Pendidikan dan Kebudayaan.

(2018). Buku Pegangan Pembelajaran Berorientasi pada Keterampilan Berpikir Tingkat Tinggi: Direktorat Jenderal Guru dan Tenaga Kependidikan Kementerian Pendidikan dan Kebudayaan.

Nurhikmah, Sudarman Bennu dan Sutji Rochaminah. (2016). Pe-nerapan Model Pembelajaran Kooperatif Tipe Think Pair Share untuk Meningkatkan Ke-mampuan Komunikasi Mate-matis Pada Materi Aritmatika Sosial Siswa Kelas VII Smp Negeri 9 Palu. e-Jurnal Mitra Sains. 4 (4), 92-101. Diperoleh pada tanggal 27 Maret 2019 dari

http://jurnal.untad.ac.id/jurnal/index.php/MitraSains/article/download/7040/5671

Sugiyono. (2012). Metode Penelitian Pendidikan (Pendekatan Kuan-titatif, Kualitatif, dan $R \& D)$. Bandung: Penerbit Alfabeta.

Wati, I. (2016). Peningkatan Kerja-sama pada Materi Perubahan Benda Menggunakan Model Pembelajaran Cooperative Tipe STAD. Jurnal Penelitian Pen-didikan Indonesia. 1 (1). 20. Diperoleh pada 15 Oktober 2018 dari https://i-rpp.com 